\title{
MODEL PEMBELAJARAN MAKE A MATCH SEBAGAI UPAYA MENINGKATKAN HASIL BELAJAR MATERI BENTUK ALJABAR
}

\author{
Sri Kardana \\ SMP Negeri 4 Tawangsari \\ Email: $\underline{\text { srikardana_dana@yahoo.co.id }}$
}

\begin{abstract}
Abstrak
Penelitian ini bertujuan untuk meningkatkan hasil belajar matematika materi Bentuk Aljabar siswa melalui model pembelajaran kooperatif tipe make a match pada siswa kelas VIII A SMP Negeri 4Tawangsari semester I tahun pelajaran 2016/ 2017. Penelitian ini adalah Penelitian Tindakan Kelas yang dilakukan di kelas VIII A SMP Negeri 4Tawangsari semester I tahun pelajaran 2016/ 2017 yang berjumah 26 siswa. Teknik pengumpulan data yang digunakan adalah tes, observasi, dan dokumentasi.Tahap-tahap analisis data dalam penelitian ini adalah pengumpulan data, reduksi data, penyajian data, dan penarikan kesimpulan. Indikator keberhasilan adalah nilai rata-rata tes siswa sekurang-kurangnya 71,0 dan banyak siswa dengan nilai di atas kriteria ketuntasan minimal (KKM) yaitu 70,0 mencapai $\geq 80 \%$.Berdasarkan penelitian yang telah dilakukan, dapat disimpulkan bahwa penerapan model pembelajaran kooperatif tipe make a match dapat meningkatkan hasil belajar matematika materi Bentuk aljabar siswa kelas VIII A SMP Negeri 4Tawangsari. Sebelum tindakan/prasiklus,hasil belajar siswa yang mencapai KKM 11 siswa atau 42,30\%, pada siklus I, 18 siawa atau 69,23\% dan pada siklus II, 22 siswa atau $84,61 \%$. Nilai rata-rata kelas sebelum tindakan/prasiklus sebesar 66,6 setelah tindakan siklus I sebesar 71,10 dan setelah tindakan siklus II sebesar 73,4
\end{abstract}

Kata Kunci: Model pembelajaran make a match, hasil belajar

\begin{abstract}
This study aims to improve the learning outcomes of the matematics material Agebraic Forms learning model type make a match in students of class VIII A SMP Negeri 4Tawangsarifirst semester academic year 2016/2017.This research is a Classroom Action Research conducted in class VIII A SMP Negeri 4Tawangsarifirst semester of academic year 2016/2017 with 26 students. Data collection techniques used are tests, observations, and documentation. The stages of data analysis in this study are data collection, data reduction, data presentation, and conclusion. The success indicator is the average score of the student's test at least 72.0 and many students with a value above the minimum mastery criteria (KKM) of 70,0 reach $\geq 84 \%$.Based on the research that has been done, it can be concluded that the application of cooperative learning model type make a match can improve learning result of matematics material of Agebraic Forms letters student of class VIII A SMP Negeri 4Tawangsari. Before the action / pre cycle, student learning
\end{abstract}


outcomes reaching KKM 11 students or $42,3 \%$, in cycle I, 18 students or $69,23 \%$ and in cycle II, 22 students or $84,61 \%$. The average value of the class before the action / pre cycle was 66,6 after the first cycle action was $71,1,9$ and after the second cycle action was 73,4 .

Keywords: Cooperative learning model type make a match, learning result mathematics.

\section{PENDAHULUAN}

Banyak siswa yang sulit dalam memahami penjelasan yang disampaikan oleh guru matematika, membuat siswa acuh dan bahkan tidak mau memperhatikan pelajaran. Pembelajaran matematika tidaklah sulit untuk dapat dipelajari, dengan menggunakan model yang tepat akan membuat siswa mudah dalam memahami materi yang disampaikan oleh guru, siswa juga tidak mudah bosan, dan dengan adanya media pembelajaran juga turut membantu siswa dalam memahami materi yang disampaikan.

Berdasarkan hasil pengamatan penulis dengan teman sejawat di SMP Negeri 4 Tawangsari, masalah yang dihadapi siswa adalah masih rendahnya hasil belajar matematika yang dimiliki oleh siswa.Hal ini disebabkan oleh siswa yang kurang aktif dalam pembelajaran berlangsung, siswa yang tidak mau berfikir dalam menyelesaikan soal, siswa yang kurang lancar dalam berbicara matematika, karena siswa kurang latihan mengerjakan soal. Rendahnya hasil belajar siswa dapat dilihat dari hasil nilai matematika yang kebanyakan masih di bawah standart ketuntasan belajar yaitu 70,0. Selain itu penulis juga mendapatkan informasi dari siswa di SMP Negeri 4 Tawangsari, bahwa metode yang digunaka oleh guru yaitu ceramah, diskusi, dan penugasan juga membuat siswa bosan pada saat mengikuti pembelajaran. Ini membuat siswa menjadi pasif, ada juga takut pada saat mengikuti pembelajaran, dan membuat hasil belajar siswa menurun. Tidak tercapainya nilai KKM yang telah ditetapkan oleh sekolah yaitu 70,00. Di dalam kelasVIII A terdapat 26 siswa, sedangkan siswa yang tuntas didalam 1 kelas hanya ada sekitar 11 siswa, dan sebagian besar siswa masih banyak yang sulit dalam memahami menjelasan materi dari guru, dapat dikatakan siswa yang masih belum tuntas memiliki persentase $58 \%$, sedangkan siswa yang sudah tuntas ada $42 \%$. 
Menurut Darsono (dalam Isjoni, 2011: 23) aliran behavioristik, pembelajaran adalah usaha guru untuk membentuk tingkah laku yang diinginkan dengan menyediakan lingkungan atau stimulus, dan aliran kognitif mendefinisikan pembelajaran adalah sebagai cara guru memberikan kesempatan kepada siswa untuk berpikir agar mengenal dan memahami sesuatu yang dipelajari.

Salah satu model pembelajaran yang dapat digunakan dalam proses pembelajaran adalah model pembelajaran kooperatif tipe make a match. Dimana model ini dikembangkan untuk mencapai hasil belajar yang berupa prestasi akademik, toleransi, mencapai keragaman dan perkembangan keterampilan sosial. Dengan model ini diharapkan siswa akan lebih aktif dalam bertanya dan dalam penyampaian pendapat, siswa juga diharapkan akan lebih dapat bersosialisasi dengan teman mereka dan dapat mengumpulkan banyak informasi tentang materi pembelajaran yang belum mereka ketahui sebelumnya. Selain itu, model pembelajaran kooperatif tipe make a match ini juga memiliki kelebihan karena pembelajaran disusun dalam bentuk kelompok, dimana terdapat kelompok pembawa kartu pertanyaan, kelompok pembawa kartu jawaban, dan kelompok penilai. Sehingga model ini dianggap sebagai model yang dapat meningkatkan prestasi belajar matematika siswa. Namun perlu diadakan penelitian untuk dapat menyimpulkan bahwa modelmake a match dapat meningkatkan prestasi belajar siswa terutama dalam pembelajaran matematika.

Menurut pendapat dari beberapa ahli tentang pembelajaran kooperatif tipe make a macth sebagai berikut: (1) Menurut Suprijono (2009 : 94) mengatakan pembelajaran kooperatif tipe make a match adalah pembelajaran yang menggunakan kartu-kartu; (2) Menurut Unodan Mohamad mangatakan pembelajaran kooperatif tipe make a match adalah pembelajaran yang menggunakan media berupa kartu pertanyaan dan kartu jawaban; (3) Pembelajaran kooperatif tipe make a match merupakan salah satu tipe pembelajaran kooperatif yang merupakan metode pembelajaran dengan membentuk kelompok-kelompok kecil yang juga bertujuan untuk berinteraksi antar siswa, yang mengajarkan kepada siswa bahwa untuk mencapai sesuatu tidak 
dapat dicapai secara sendiri, melainkan dikerjakan bersama-sama. Mengajarkan kepada siswa untuk dapat berinteraksi dan bergaul dengan siswa yang lain tanpa membedakan ras, suku, dan agama. Pembelajaran kooperatif tipe make a match ini membagi siswa menjadi beberapa kelompok yaitu kelompok pembawa kartu pertanyaan,kelompok pembawa kartu jawaban, dan sebagai kelompok penilai.

Siswa diajarkan untuk belajar bersama dengan siswa yang lain, saling bertukar informasi yang mereka miliki, dan mengajarkan sportifitas dalam kegiatan kelompok tersebut. Pembelajaran kooperatif tipe make a match ini adalah variasi dalam kegiatan kelompok yang sebelumnya pernah ada, dengan penggunaan metode ini diharapkan siswa dapat lebih aktif didalam menerima pembelajaran dan diharapkan siswa tidak bosan dan lebih mudah dalam menerima penjelasan yang diterangkan oleh guru yang membuat peningkatan prestasi belajar siswa terutama pada pembelajaran matematika.

Langkah-langkah kegiatannya adalah sebagai berikut : (1) Guru membagi siswa dibagi dalam beberapa kelompok, setiap kelompok terdiri dari 2-4 siswa yang masing-masing dalam kelompok memiliki peran yaitu kelompok pembawa kartu pertanyaan, dan kelompok pembawa jawaban; (2) Guru menyiapkan beberapa kartu yang berisi beberapa konsep atau topik yang cocok untuk sesi review, satu untuk bagian kartu soal dan bagian lainnya kartu jawaban.Setiap siswa mendapat satu kartu; (3) Setiap siswa memikirkan jawaban atau soal kartu yang dipegang; (4) Kemudian setiap siswa mencari pasangan yang mempunyai kartu yang cocok dengan kartu yang mereka bawa; (5) Setiap siswa yang telah mendapatkan pasangan kartunya yang cocok sebelum waktu yang ditentukan habis akan diberikan tambahan poin oleh guru; (6) Setelah satu babak kemudian kartu dikocok lagi agar tiap siswa mendapat kartu yang berbeda dari kartu sebelumnya, demikian seterusnya.Kemudian diakhir kegiatan guru bersama-sama dengan siswa menyimpulkan dari materi yang telah dipelajari.

Alternatif yang dapat ditempuh dalam meningkatkan hasil belajar siswa adalah melalui kreatifitas guru dalam memilih model pembelajaran.Pemilihan model pembelajaran yang tepat dan bervariasi dapat meningkatkan hasil belajar siswa terutama dalam mata pelajaran matematika. Karena tidak semua model 
cocok digunakan dalam penyampaian materi, kreativitas guru sangatlah diperlukan dalam pemilihan model pembelajaran yang akan digunakan. Dengan menggunakan model pembelajarana yang tepat dan bervariasi dalam penyampaian materi dapat membantu siswa untuk meningkatkan ide, gagasan dan kreativitas yang dimiliki siswa. Peran guru sebagai fasilitator sangatlah membantu siswa mengembangkan kreativitas yang mereka miliki, siswa juga akan dituntut untuk aktif dalam proses pembelajaran, ini membuat siswa menjadi lebih bersemangat dan bertanggung jawab dalam menemukan hasil jawaban yang diberikan kepada siswa. Pembentukan kelompok juga sangat berguna dalam meningkatkan hasil belajar siswa terutama pada mata pelajaran matematika, siswa juga akan belajar untuk bersosialisasi dengan teman yang lain, dengan demikian akan menjalin kekompakan dan kerja sama dalam menemukan solusi dari masalah yang diberikan kepada siswa. Pembentukan kelompok akan membuat siswa menjadi senang dalam mengikuti pembelajaran dan tujuan yang didasarkan pada alasan bahwa untuk mencapai sesuatu tidak dapat dicapai secara sendiri, melainkan harus dikerjakan secara bersama-sama, hal ini akan meningkatkan kekompakan, keaktifan, serta kerja sama. Siswa memungkinkan dapat meraih keberhasilan dalam belajar, di samping itu juga akan melatih siswa untuk meningkatkan keterampilan berpikir, dan keterampilan sosial seperti mengemukakan pendapat, menerima saran, bekerja sama dan rasa setia kawanan.

Berdasarkan latar belakang di atas, maka dapat dirumuskan masalah, "Apakah dengan menerapkan model pembelajaran kooperatif tipemake a match dapat meningkatkan hasil belajar materi Aljabarpada siswa kelas VIII A SMP Negeri 4 Tawangsari semester I tahun pelajaran2016/ 2017?”.

\section{METODE PENELITIAN}

Penelitian ini adalah Penelitian Tindakan Kelas. Penelitian tindakan kelas merupakan suatu pencermatan terhadap kegiatan yang sengaja dimunculkan, dan terjadi dalam sebuah kelas (Arikunto, 2010: 130).Penelitian ini dilaksanakan di SMP Negeri 4 Tawangsari.Tahap-tahap pelaksanaan kegiatan dilakukan selama kurang lebih lima bulan yaitu sejak bulan Juli sampai dengan November 
2016.Peneliti sebagai guru SMP Negeri 4 Tawangsari bertindak sebagai subjek yang melakukan tindakan kelas.Teman sejawat sesama guru mata pelajaran matematika sebagai observer.Kepala Sekolah bertindak sebagai subjek yang membantu dalam perencanaan dan pengumpulan data. Subjek yang menerima tindakan adalah siswa kelas VIII ASMP Negeri 4Tawangsari semester I tahun pelajaran 2016/2017 sebanyak 26 siswa.Adapun langkah-langkah penelitian untuk setiap siklus pembelajaran adalah sebagai berikut:

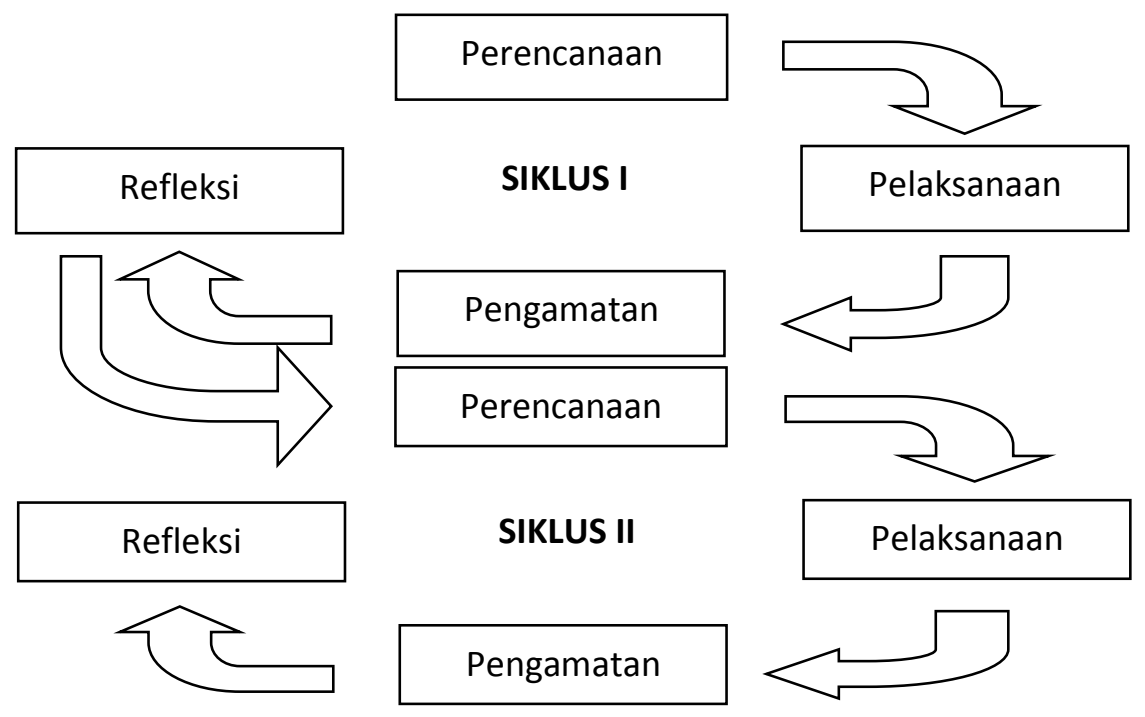

Gambar 1. Siklus Penelitian Tindakan (Arikunto, 2006:137)

Teknik pengumpulan data yang digunakan adalah: tes, observasi dan dokumentasi. Tes adalah serentetan pertanyaan atau latihan serta alat lain yang digunakan untuk mengukur keterampilan, pengetahuan inteligensi, kemampuan atau bakat yang dimiliki oleh individu dan kelompok (Arikunto, 2010 : 193). Tes digunakan adalah jenis tes hasil (achievement test) berupa kuis individu.Tes ini digunakan untuk mengukur pencapaian siswa setelah mempelajari materi. Hal ini dapat juga sebagai alat untuk mengetahui tingkat pemahaman siswa setelah mempelajari materi bentuk Aljabar dengan menggunakan model pembelajaran kooperatif tipe Make a Match .Kuis individu yang dimaksudkan ini adalah tes tertulis. Tes tertulis adalah suatu teknik penilaian yang menunutut jawaban secara tertulis, baik berupa pilihan atau isian. Tes yang jawabannya berupa pilihan 
meliputi pilihan ganda, benar salah dan menjodohkan, sedangkan tes yang jawabannya berupa isian berbentuk isian singkat atau uraian (Suprijono, 2013:138).Observasi atau pengamatan dilakukan guna memperoleh data yang akurat, dengan menggunakan lembar observasi.

Lembar observasi digunakan untuk memonitor dan mengevaluasi setiap tindakan agar kegiatan observasi tidak terlepas dari konteks permasalahan dan tujuan penelitian. Observasi yang digunakan adalah observasi sistematis, yaitu observasi yang dilakukan oleh pengamat dengan menggunakan pedoman sebagai instrumen pengamatan dan observasi non-sistematis yang dilakukan dengan tidak menggunakan instrumen pengamatan.Dokumentasi diperoleh dari hasil kuis siswa, lembar observasi, lembar wawancara, catatan lapangan, daftar siswa, dan foto-foto selama proses kegiatan belajar mengajar. Dokumentasi ini dimaksudkan adalah sebagai bukti-bukti konkret dari penelitian tindakan kelas tersebut.

Instrumen yang digunakan dalam penelitian berupa tes, lembar observasi dan lembar dokumentasi. Tes berbentuk tes tertulis maupun lisan yang dilakukan dalam post test dan kuis individu. Tes ini digunakan untuk mengetahui sejauh mana peningkatan hasil belajar Aljabarsiswa dengan penerapan model pembelajaran kooperatif tipe Make a Match. Lembar Observasi, digunakan lembar observasi hasil belajar siswa dan lembar observasi pelaksanaan pembelajaran kooperatif. Lembar observasi digunakan pada setiap pembelajaran sehingga kegiatan observasi tidak terlepas dari konteks permasalahan dan tujuan penelitian, untuk lembar hasil belajar siswa digunakan pada saat siswa dapat menyelesaikan permasalahan dengan kegiatan belajar mengajar dan sedangkan lembar observasi pelaksanaan kegiatan belajar mengajar dengan model pembelajaran Kooperatif Tipe Make a Match digunakan sebagai pedoman peneliti dalam melakukan observasi pelaksanaan kegiatan belajar mengajar dengan menggunakan model pembelajaran kooperatif tipe Make a Match . Lembar dokumentasi ini bertujuan untuk mengetahui data siswa selama kegiatan penelitian berlangsung. Lembar dokumentasi ini berupa, foto-foto kegiatan pembelajaran, daftar hadir kegiatan pembelajaran, daftar hadir, daftar nilai, kartu pasangan soal/jawaban dan sebagainya. 
Indikator keberhasilan kinerja dalam penelitian ini adalah meningkatnya hasil belajar matematika materi Aljabarsiswa, yang ditunjukkan dengan meningkatnya nilai rata-rata tes siswa sekurang-kurangnya 71,0 dan banyak siswa dengan nilai di atas kriteria ketuntasan minimal (KKM) yaitu $\geq 70,0$ mencapai $\geq$ $80 \%$.

\section{HASIL PENELITIAN DAN PEMBAHASAN}

\section{a. Hasil Penelitian}

Deskripsi data hasil penelitian yang telah dilakukan di kelas VIII A SMP Negeri 4 Tawangsari adalah sebagai berikut. Berdasarkan observasi awal di kelas VIII A mata pelajaran matematikadengan materi Bentuk Aljabar diperoleh data, dari 26 siswa yang mencapai nilai kriteria ketuntasan minimal (KKM) sebanyak 11 siswa (42,30\%), dengan nilai rata-rata kelas sebesar 66,6. Penelitian ini dilakukan dengan indikator kinerja nilai rata-rata tes siswa sekurang-kurangnya 71,0 dan banyak siswa dengan nilai di atas kriteria ketuntasan minimal (KKM) yaitu $\geq 70,0$ mencapai $\geq 80 \%$.

Kemudian peneliti merencanakan observasi survai berikutnya untuk mengetahui kebenarannya.Pada kegiatan survei awal yang dilaksanakan pada hari Rabu, 27 Juli 2016. Hasil observasi awal menunjukkan bahwa guru yang mendominasi kegiatan pembelajaran dan siswa cenderung tidak aktif. Salah satu solusi yang dikembangkan adalah penggunaan model pembelajaran yang baru yaitu dengan Model Pembelajaran Kooperatif Tipe Make a Match (mencari pasangan). Dengan penggunaan model pembelajaran tersebut diharapkan akan menciptakan suasana belajar yang berbeda, bervariasi dan menyenangkan sehingga dapat menarikperhatian siswa, meningkatkan keaktifan siswa yang muara akhirnya meningkatkan hasil belajar siswa.

Tindakan kelas siklus I dilaksanakan pada hari Rabu, 3 Agustus 2016 di SMP Negeri 4 Tawangsari kelas VIII A. Setelah langkah apersepsi dilanjutkan dengan penyampaian materi dengan model pembelajaran kooperatif tipe make a 
match. Berdasarkan hasil evaluasi pada siklus I menunjukkan adanya peningkatan hasil belajar siswa. Hasil belajar siswa sebanyak 18 mencapai nilai kriteria ketuntasan minimal (KKM) atau 69,23\%, rata-rata kelas naik menjadi 71,1. Berdasarkan pengamatan tersebut dapat diketahui bahwa proses pembelajaran pada siklus pertama belum berhasil maksimal dan belum mencapai indikator kinerja yang diharapkan. Peningkatan hasil, jika dibandingkan hasil prasiklus yang mencapai KKM sebanyak 11 siswa atau 42,3\% setelah diberi tindakan penerapan siklus I, siswa yang mencapai KKM sebanyak 18 siswa atau 69,23\%.

Tabel 1.Perkembangan Siswa yang Mencapai KKM Sebelum Tindakan/Prasiklus ke Siklus I

\begin{tabular}{lcc}
\hline \multicolumn{1}{c}{ Hasil Siswa } & Prasiklus & Siklus I \\
\hline Siswa mencapai KKM & 11 & 18 \\
\hline
\end{tabular}

Dari tabel di atas dapat disimpulkan bahwa hasil belajar matematika materi Aljabarsiswa dengan menerapkan model pembelajaran kooperatif tipe make a match, padapelaksanaan tindakan siklus I mengalami peningkatan. Siswa yang mencapai KKM Sebelum dilakukan tindakan atau prasiklus 11 siswa, setelah tindakan siklus I sebanyak 18 siswa sehingga meningkat 7 siswa.

Setelah dievaluasi bersama dari pelaksanaan tindakan pada siklus I yang digunakan sebagai bagian pertimbangan perencanaan pembelajaran siklus berikutnya, dengan perencanaan perbaikan untuk mengatasi kekurangan dan kesalahan yang dilakukan pada siklus I. Tindakan kelas siklus II dilaksanakan pada hari Rabu, 10Agustus 2016. Berdasarkan pembelajaran secara keseluruhan pada tindakan kelas siklus II menunjukan adanya peningkatan yang signifikan. Hasil belajar siswa sebanyak 22 siswa $(84,61 \%)$ mencapai nilai kriteria ketuntasan minimal (KKM). Sehingga rata-rata nilai kelas VIII A naik menjadi 73,4.

Tabel 2. Perkembangan Siswa yang Mencapai KKM Siklus I ke Siklus II

\begin{tabular}{ccc}
\hline Hasil Siswa & Siklus I & Siklus II \\
\hline Siswa mencapai KKM & 18 & 22 \\
\hline
\end{tabular}


Dari tabel 2 di atas dapat disimpulkan bahwa hasil belajar materi Aljabar siswa dengan menerapkan model pembelajaran kooperatif tipe make a match, pada pelaksanaan tindakan siklus II mengalami peningkatan. Siswa yang mencapai KKM pada saat dilakukan tindakan siklus I sebanyak 18 siswa, setelah tidakan siklus II sebanyak 22 siswa sehingga meningkat 4 siswa.Berdasarkan hasil tersebut dapat diketahui bahwa proses pembelajaran sampai dengan pada siklus II berjalan dengan baik dan telah memenuhi indikator kinerja yang diharapkan.

\section{b. Pembahasan}

Pada siklus I dan II dengan penerapan tindakan menggunakan model pembelajaran kooperatiftipe make a match, sehingga siswa lebih antusias dengan perasaan senang dalam mengikuti kegiatan pembelajaran. Nilai rata-rata siswa sejak sebelum diadakan penelitian hingga setelah diadakan penenelitian sampai dengan siklus II, dapat dilihat pada tabel berikut:

Tabel 3. Perkembangan Siswa yang Mencapai KKM Prasiklus,Siklus I dan Siklus II Hasil Siswa Prasiklus Siklus I Siklus II

\begin{tabular}{llll}
\hline Siswa mencapai KKM & 11 & 18 & 22 \\
\hline
\end{tabular}

Dari tabel 3 di atas dapat disimpulkan bahwa hasil belajar materi Aljabar siswa dengan menerapkan model pembelajaran kooperatif tipe make a match, di setiap pelaksanaan tindakan, baik siklus I dan siklus II mengalami peningkatan, yaitu: siswa yang mencapai KKM Sebelum dilakukan tindakan atau prasiklus 11 siswa, setelah tidakan siklus I sebanyak 18 siswa dan setelah tindakan siklus II sebanya 22 siswa, sehingga peningkatan kumulatif dari sebelum tindakan/prasiklus sampai dengan siklus II sebesar 11 siswa.

Tabel 4. Perkembangan Persentase Siswa Mencapai KKM Prasiklus, Siklus I dan SiklusII

\begin{tabular}{cccc}
\hline Hasil Siswa & Prasiklus & Siklus I & Siklus II \\
\hline Persentase Siswa mencapai KKM & $42,30 \%$ & $69,23 \%$ & $84,61 \%$ \\
\hline
\end{tabular}


Dari tabel di atas dapat disimpulkan bahwa hasil belajar Aljabarsiswa dengan menerapkan model pembelajaran kooperatif tipe make a match, di setiap pelaksanaan tindakan mengalami peningkatan, yaitu: persentase siswa yang mencapai KKM Sebelum dilakukan tindakan atau prasiklus 42,30\%, setelah tidakan siklus I sebanyak 69,23\% dan setelah tindakan siklus II sebanya 84,61\%.

Tabel 5. Perkembangan Nilai Rata-rata KelasSebelum Tindakan/Prasiklus, Siklus I dan Siklus II

\begin{tabular}{cccc}
\hline Hasil Siswa & Prasiklus & Siklus I & Siklus II \\
\hline Nilai Rata-Rata & 66,6 & 71,08 & 73,4 \\
\hline
\end{tabular}

Dari tabel 5 dapat disimpulkan bahwa hasil belajar materi Aljabarsiswa dengan menerapkan model pembelajaran kooperatif tipe make a match, di setiap pelaksanaan tindakan mengalami peningkatan, yaitu: nilai rata-rata kelas sebelum dilakukan tindakan atau prasiklus adalah 66,6, setelah tidakan siklus I adalah 71,08 dan setelah tindakan siklus II adalah 73,4 sehingga dari kondisi awal sebelum tindakan/prasiklus sampai dengan tidakan pada siklus II terjadi peningkatan sebesar 6,8.Dari uraian di atas dapat disimpulkan bahwa model pembelajaran kooperatif tipe make a match dapat meningkatkan hasil belajarmateri Aljabarsiswa kelas VIII A SMP Negeri 4 Tawangsarisemester I tahun pelajaran 2016/ 2017.

\section{SIMPULAN}

Berdasarkan hasil penelitian dapat disimpulkan, dengan penerapan model pembelajaran kooperatif tipe make a match dapat meningkatkan hasil belajar materi Bentuk Aljabar siswa kelas VIII A SMP Negeri 4Tawangsari semester Itahun pelajaran2016/ 2017. Penelitian Tindakan Kelas (PTK) yang dilaksanakan di SMP Negeri 4 Tawangsari ini sudah berjalan dengan cukup baik dan hasil yang baik pula. Namun masih banyak hal yang perlu diperbaiki. Oleh karena itu, peneliti memberikan beberapa saran. (1) Siswa diharapkan dapat lebih meningkatkan 
kemampuan diri melalui peran aktifnya dalam mengikuti kegiatan belajar mengajar. Peran aktif tersebut meliputi peran aktif dalam bertanya, mengemukakan pendapat maupun mempresentasikan gagasannya. (2) Guru matematika hendaknya dapat menumbuh kembangkan kreativitas dalam menjalankan profesinya sebagai fasilitator dan motivator dalam menyampaikan pembelajaran secara kreaktif dan inovatif pada siswa dalam penyampaian materi, sehingga siswa dapat menerima dan memahami materi yang diajarkan dengan baik. (3) Penelitian Tindakan Kelas (PTK) ini diharapkan akan membawa dampak positif terhadap perkembangan sekolah yang nampak pada peningkatan prestasi belajar siswa sehingga dapat meningkatkan prestasi dan kualitas sekolah.

\section{DAFTAR PUSTAKA}

Arikunto, S. 2006. Prosedur Penelitian Suatu Pendekatan Praktik. Jakarta: Rineka Cipta.

Aunurrahman. 2009. Belajar dan Pembelajaran, Bandung : Alfabeta.

Ayu Febriana. 2011. Penerapan Model Pembelajaran Kooperatif Tipe Make A Match Untuk Meningkatkan Kualitas Pembelajaran IPS Siswa Kelas V SDN Kalibanteng Kidul 01 Kota Semarang(Application Of Cooperative Learning Model Type Make A Match To Enhance Quality Of Learning Social). Jurnal Kreatif: Jurnal Kependidikan DasarVol 1, No 2 (2011).

Dimyati dan Mudjiono. 2009. Belajar dan Pembelajaran. Jakarta: Rineka Cipta.

Hamalik, Oemar. 2004. Proses Belajar Mengajar. Jakarta: Bumi Aksara.

Isjoni. 2007. Cooperative Learning Efektifitas Pembelajaran Kelompok. Bandung: Alfabeta.

Mikran Mikran, Marungkil Pasaribu, I Wayan Darmadi. 2014. Penerapan Model Pembelajaran Kooperatif Make A Match untuk Meningkatkan Hasil Belajar Siswa Kelas VIIA SMP Negeri 1 Tomini pada Konsep Gerak. Jurnal Untad Vol 2, Bo 2 (2014).

Mustika Purnamasari, J. S. Sukardjo, Agung Nugroho C. S. 2013. Studi Komparasi Pembelajaran Kooperatif Tipe Numbered Head Together (NHT) dan Make A Match (MM) pada Materi Koloid terhadap Hasil 
Belajar Siswa Kelas XI SMA Negeri Kebakkramat Tahun Pelajaran 2011/2012. Jurnal Pendidikan KimiaVol 2, No 1 (2013).

Nurlia Astika, Ngurah Ayu Nyoman M. 2012.Efektivitas Model Pembelajaran Kooperatif Tipe Make A-Match terhadap Hasil Belajar Siswa. Jurnal Penelitian PembelajaranFisikaVol 3, No 2 (September2012).

Poerwodarminto.2003. Kamus Umum Bahasa Indonesia. Jakarta: Balai Pustaka.

Rudi Salam, Zunaira Zunaira, Risma Niswaty. 2012. Meningkatkan Hasil Belajar Membuat Dokumen Melalui Penggunaan Model Pembelajaran Kooperatif Tipe Make A Match (Mencari Pasangan).Jurnal Office Vol 2, No 2 (Juli-Sept 2012).

Suprijono, Agus. 2009. Cooperative Learning Teori dan Aplikasi Paikem. Yogyakarta: Pustaka Pelajar. 